Ayad Hayawi al Atabi. Analysis of the use of modern information and communication...

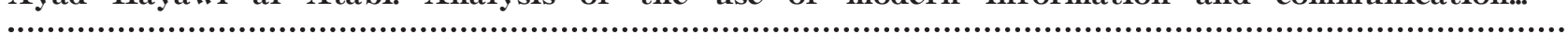

UDC 378:75.049

DOI https://doi.org/10.24919/2308-4863/36-1-29

Dr. Ayad HAYAWI AL ATABI,

orcid.org/0000-0002-9289-8596

Candidate of Fine Arts,

Media College

of Thi-Kar University

(NasiriyahDhi Qar,Iraq)ayad_hayawi@utq.edu.iq

\title{
ANALYSIS OF THE USE OF MODERN INFORMATION AND COMMUNICATION TECHNOLOGIES FOR TECHING FUTURE ARTISTS
}

The crisis situation in the educational sphere is actively being realized, which is expressed in the differences between social needs in this area and the possibility of their satisfaction. Therefore, it becomes necessary to guarantee that the education is in line with the dynamic changes that occur in the environment, the increasing information volumes, the rapid implementation of information and communication technologies. The article reveals some aspects of the use of information and communication technologies for teaching future artists. The directions of using information and communication technologies as a teaching tool, a means of information support for training and a tool for professional activity are identified. The use of the computer in the design, artistic and creative activities of students is considered. Computer technologies, which are positioned as a necessary tool for increasing the efficiency and improving the quality of education, allow future artists to find the best ways to implement their projects. An overview of modern electronic devices for drawing is presented; the advantages of their use in comparison with traditional drawing techniques are revealed. It was noted that the greatest efficiency of quality education is achieved through personal communication, therefore, the use of webinars, network blogs and wiki technologies is relevant. So, substantiating the possibilities and basic means of information and communication technologies, it is necessary to identify the main qualities of thinking, integrative skills and abilities, which contribute to the creative realization and artistic self-fulfilment using computer technologies. All presented abilities can be referred to as properties of design thinking. The field of innovative electronic technologies requires project thinking from the future artist, will help in his professional activity to build a clear structure with certain stages of the implementation of creative activity to create an interactive work of art.

Thus, information and communication technologies stimulate the cognitive motivation of students, form a system of knowledge, skills and abilities of a specialist in the search, processing, transfer and storage of professionally significant information.

Key words: artist, information and communication technologies, professional competence, project, computer technology.

д-р Аяд ХАЯВІ АЛЬ АТАБІ,

orcid.org/0000-0002-9289-8596

кандидат наук з образотворчого мистецтва,

Коледж медіакомунікаиій

Університету в Ti-Kapi

(Насирія, Ti-Kap, Ірак)ayad_haywi@utq.edu.iq

\section{АНАЛІЗ ВИКОРИСТАННЯ СУЧАСНИХ ІНФОРМАЦЙНИХ І КОМУНІКАЦІЙНИХ ТЕХНОЛОГІЙ У ПРОЦЕСІ НАВЧАННЯ МАЙБУТНІХ ХУДОЖНИКІВ}

\footnotetext{
Нині активно здійснюється усвідомлення кризової ситуації в освітній сфері, яка виражається у відмінностях між соиіальними потребами в иій сфері й можливістю їх задоволення, тому на основі вищесказаного виникає необхідність гарантувати адекватність освіти відповідно до динамічних змін, які відбуваються в навколишньому середовищі, збільшення кількості інформащіï, стрімкий розвиток у сфері впровадження інформаційних $i$ комунікаційних технологій.

Сьогодні виникла необхідність підвищення рівня художньої освіти в Україні на основі розробки стратегії й тактики викладання дисциилін художнього профілю, відповідно до національної концепції освіти України. Обмеженість концептуальних ресурсів традиційної системи освіти зумовила постановку питання про зміну самої парадигми й моделі освіти. У статті розкриваються деякі аспекти використання інформаційно-комунікаційних технологій у процесі навчання майбутніх художників. Розкрито напрями використання інформаційнокомунікаційних технологій як інструменту навчання, засоби інформаційної підтримки навчання й інструменту професійної діяльності. розглядаються використання комп'ютера в проектній $і$ художньо-творчій діяльності
} 
студентів. Комп'ютерні технологї̈, щзо позииіонуються як необхідний інструмент підвищення ефективності та якості навчання, дають змогу майбутнім художникам знаходити оптимальні шляхи реалізації своїх проектів. Наведено огляд сучасних електронних пристроїв для малювання; розкрито переваги їх використання в порівнянні з традииійними техніками малювання. Художня освіта є тією сферою, де активно використовують комп 'ютерні технології, передусім графічні програми. Створення композииї зображення як окремого об'єкта, так $і$ сакральних просторів, розробка його контурного рішення, потім роботанад колірним спектром єтворчим процесом. Відзначено, щчо найбільша ефективність у досягненні високої якості освіти досягається при особистому спілкуванні, тому актуальним є застосування вебінарів; мережевих блогів і вікі-технологій.

Отже, інформаційно-комунікаційні технології стимулюють пізнавальну мотивацію студентів, формують систему знань, умінь і здібностей фахівия з пошуку, обробки, передачі та зберігання професійно значимої інформачїі.

Ключові слова: художник, інформаційно-комунікаційні технологї̈, професійна компетентність, проект, комп 'ютерні технологіі.

Research topicality. The crisis situation in the educational sphere is actively being realized, which is expressed in the differences between social needs in this area and the possibility of their satisfaction. Therefore, it becomes necessary to guarantee that the education is in line with the dynamic changes that occur in the environment, the increasing information volumes, the rapid implementation of information and communication technologies.

Today, there is a need to improve the level of art education in Ukraine on the basis of developing a strategy and tactics for teaching art disciplines in accordance with the national concept of education in Ukraine. The limited conceptual resources of the traditional education system led to the need to change the paradigm and model of the education itself. The problems of informatization are especially pressing among the most important scientific, technical and socio-economic problems, that is, the creation of a system to effectively provide timely, reliable and comprehensive materials for all socially important types of human activity, conditions for a prompt, thorough and comprehensive analysis of the processes and phenomena under study, their forecasting, anticipation of the decision-making implications.

Thus, information and communication technologies (hereinafter - ICTs) are one of the innovative learning technologies. The use of information and communication technologies in the work of specialists of various profiles, effective communication between them, the use of information resources to realize the intellectual potential of society determines the level of informatization of modern society. It refers to all areas of development of society, causes the need to increase the level of knowledge of ICT tools both by individuals and by groups of specialists, aimed at creating optimal conditions for meeting information needs based on the use of information resources (Kalinkina, 2016: 123).

The current state of training future artists necessitates the use of information and communication technologies in the process of professional development of a specialist. Many higher educational institutions introduce subjects using professionally oriented programs in the form of electives. However, the existing training of specialists, which is focused exclusively on the system of knowledge of certain subjects, cannot be considered satisfactory.

Review of recent research. Many scholars studied the use of ICT tools in the professional training of future specialists for professional activity in the information society, namely V. Bykov, A. Verlan, A. Ershov, N. Morze, S. Rakov, S. Schwarzburd and others. In their research, P. Galperin, Yu. Mashbits, N. Talyzin considered psychological foundations for studying the problems of informatization of the educational process.

In the process of carrying out a comprehensive analysis of the indicated problem, we focused on the research of Ukrainian and foreign scholars in the artistic field, namely O. Bodnar, V. Danilenko, M. Stankevich, Y. Laschuk, A. Fedoruk and others.

One of the most active factors that negatively affect the practical solution of the problem under consideration is the insufficient level of development of methodological systems for teaching various subjects to students who study art by means of information and communication technologies.

The theoretical and practical significance of the improvement in the methodological system of education based on information and communication technologies is so great that it acquires the status of a separate scientific problem. Various aspects of its solution are reflected in the works of A. Ershov, V. Zhitomirsky, M. Zhaldak, V. Zavarykin, V. Lapinsky, Y. Mashbits, Y. Ramsky, M. Shkil and others.

Despite the considerable attention of scholars to the problems of training future artists on the basis of information and communication technologies, an urgent problem of training has not become the topic of a separate study. As practice shows, the rapid development of computing tools, both software and hardware, does not lead to the same rapid use of information and communication simulation tools in art higher educational institutions. 
This problem, in addition to all of the above, is due to the contradictions between the requirements of society for contemporary artists and the results of their professional training.

The aim of the article: analysis of the use of modern information and communication technologies in teaching future artists.

Results. Over the past years, information and communication technologies have been introduced into the education system. It should be noted that in our time, the problem of computerization in various aspects has been largely solved. ICTs are becoming an important component of education.

Thus, modern information and communication technologies of teaching are described as original technologies (methods, means, ways) of creating, transferring and storing educational materials, as well as ways and innovative methods of their use for organizing and supporting the educational process (traditional, electronic, remote, mobile) with the help of telecommunications, computer and communication tools, which are being introduced into the pedagogical sphere to improve the quality of education and ensure high efficiency and informatization of the educational process (Blyzniuk, 2017: 15-16).

Today, the use of computer technology is relevant in higher education for training artists. At the same time, electronic technology is a space that synthesizes a large information volume.

The creation of a specific image using graphic software is a small part of the overall design activity. The visual effects that are included in computer programs are constantly being updated, and their number grow every year. Therefore, the main thing for the educational sphere in the use of computer technologies is the development of design methods.

Graphic works play a huge role in the process of teaching students studying traditional applied arts [1]. All creative and technological chains from design to manufacture of a product are based on a graphical presentation of information. The concept of computer graphics provides for the use of computer (information) technologies to create graphical two-dimensional images, including through threedimensional modelling (Morze; Ihnatenko, 2020).

Artists working in the field of design and applied arts make products on graphic tablets using a special device - a stylus, which completely replaces the usual tools (brush, pencil, airbrush) (Rudenchenko, 2017). These tablets allow drawing more expressive strokes, they are sensitive to the pressure on the stylus and the tilt of the pen while drawing.

The use of electronic devices for drawing has a number of advantages over traditional techniques, for example, the ability to work on a very large project, quickly make the necessary changes, and present several versions of it. By completing a project on a computer, the student gets certain advantages over working on paper. If the teacher makes a comment, it means that you will have to redo the sketch or the whole project, which requires a lot of time. This can be avoided by creating an image on a computer, where it is possible to quickly make any changes. At the same time, the initial version of the project is not subject to changes and there is always an opportunity to return to it or compare it with a new version.

Therefore, it should be noted that ICTs can be used in the professional training of future artists as a teaching tool (means to achieve the set pedagogical goal), providing information support for training a student at any time and at any distance (electronic lecture notes, resource materials for practical and laboratory work, term and diploma projects), information resources on the Internet (search engines, digital image databases, electronic catalogues and encyclopaedias, virtual museums, galleries, temples tours, personal websites of artists, educational subject electronic publications); as a tool of professional activity, which includes generalpurpose software products and professionally oriented towards specialized academic subjects.

Higher art educational institutions currently use traditional forms when conducting lectures and practical classes, namely: lectures, laboratory and practical work. It is possible to apply innovative information and communication technologies during those activities (multimedia presentations for lectures, resources of Internet websites, immersing students in virtual tours around galleries of world museums (for example, the GoogleArtProgect online platform allow students to access high clarity artwork kept by partner museums, and the platform allows users to take virtual tours of museum galleries, view physical and contextual information about artwork, and create their own virtual collections.

Google Glass, Oculus Rift and other devices have been developed that bring augmented virtual reality (Fursikova, 2019: 173).

For example, in art education, this technology can be used to demonstrate 3D projects in specific rooms for which products are created. With this method, we can show furniture, decorative paintings in a real environment even before they are created.

According to the above, it becomes necessary to make the following changes in the technology of teaching future artists:

- the teacher or student explains the information that is presented on the screen and, if necessary, gives examples for a better understanding of the material; 
- control in the training quality assurance system (organization and conduct of computer testing to determine the level of theoretical knowledge, computer presentations, which include test questions and exercises on the reproduction of works, presentationsdiagnostics where students determine fragments of works of fine art using computer means for associative saturation of the process of aesthetic perception).

Thus, art education is an area which actively involves computer technologies, and graphic programs above all. The creation of a composition of the image of both a separate object and sacred spaces, the development of its contour solution, then work on the colour spectrum is a creative process. The work can be performed both in office software of WINDOWS, and in graphic software - Paint, CorelDraw, Adobe Photoshop, 3D studiomax. These software products are aimed at conducting an experiment with various options for images, synthesizing various types of visual information.

For example, researcher A. Khaldibetova (Haldybetova, 2020) noted that the computer simulation, which is built on innovative graphic tools, creates an atmosphere of creativity and allows looking at the world through the eyes of a creator.

Successful development of ICTs and future specialists' clear understanding that the greatest efficiency of quality education is achieved through personal communication led to the active development and further application of a new educational information and communication technology - webinars - in teaching. The term "webinar" is an educational information and communication technology organized on the Internet through a special software for the live, mainly interactive, transfer and control of knowledge.

The webinar is characterized by interactivity. That is, the speaker makes a report, the participants ask questions and the speaker answers them. It is the chat that provides an opportunity to ask questions. At the webinar, as in a regular seminar, there is an opportunity to interact with the presenter, that is, to complete his/her assignments, answer his/her questions and ask your own. In general, webinars are a good tool that allows you to significantly expand the audience, increase the number of attendees and creates significant advantages in saving time, money and other resources, since it allows participating in the interactive educational process at a convenient time and place. The webinar allows delivering subject reports with their subsequent discussion, showing demonstration slides and other images. Also, the webinar also allows building a meeting as questions and answers sessions, when all conference participants exchange experience with each other, ask interactive questions, and receive answers to them.
In addition, it must be emphasized that the creative projects are implemented with the help of:

- Network blogs - small websites, the authors of which (bloggers) can control access to information posted on the blog: make it available either for all users, or only for a certain group of readers in order to conduct discussions on various areas of research (Rudenchenko, 2017: 29).

This technology has a number of advantages, namely: the openness of content for all participants, the speed of posting information and access to it, independence from the individual schedule of visits by blog participants, interactivity - members of the network community (students, teachers, educational institutions, district or city heads etc.) can leave their entries in the diary, read messages and publications, and provide comments.

- Wiki technologies are creating a system of linked information materials on the Internet, in which any Internet user can take part. These technologies allow to collectively develop, edit, save, structure and restructure texts, hypertext, multimedia files without knowledge of the basics of programming or any special techniques of hypertext markup (Morze; Ihnatenko, 2020: 90).

Summarizing the features of the use of ICTs in the professional training of future artists, it is necessary to emphasize that their use contributes both to the development of the teacher's professional competence in the use of ICTs, and the information competence of future artists. Thus, the following opportunities of information and communication technologies which have an impact on setting the objectives of art education can be distinguished:

1. Systemic influence on the future artist's perception;

2. Reproduction of various visual means of expression;

3. Computer technology help transform the components of the screen image into an interactive object; in addition, they allow creating models of self-developing information systems;

4. Information and communication technologies provide visualization and activate perception (Fursykova, 2018: 9).

So, substantiating the possibilities and basic means of information and communication technologies, it is necessary to identify the main qualities of thinking, integrative skills and abilities, which contribute to the creative realization and artistic self-fulfilment using computer technologies. All presented abilities can be referred to as properties of design thinking. The field of innovative electronic technologies requires project thinking from the future artist, will help in his professional activity to build a clear structure with certain stages of the implementation of creative activity to create an interactive work of art. 
The main provisions, results and conclusions of the study can be used by teachers of higher art educational institutions, practicing teachers, scholars to further substantiate the theoretical and methodological foundations of training future artists. According to our assumption, the effectiveness of training future artists will significantly increase under the following conditions:

- integration of the content of individual computeroriented academic subjects into the integrated framework of the artistic training of students;

- creation of qualitatively new educational and methodological kits for the integration of courses, which require implementing the principle of continuity and unity of the content and procedural aspects of the educational activities of students at different educational and qualification levels of training;
- integrated use of a set of didactic tools such as information and communication technologies, improved on the basis of the modular principle of building the content of the material, traditional laboratory experiments, computer simulation, testing as one of the methods to control the assimilation of the content of professional training of future artists.

Thus, informationand communication technologies stimulate the cognitive motivation of students, form a system of knowledge, skills and abilities of a specialist in the search, processing, transmission and storage of professionally significant information (scientific, art history, religious, archival), develop the skills and abilities of verbal and non-verbal communication with other people when implementing group projects, are one of the tools of the professional activity of a future specialist.

\section{BIBLIOGRAPHY}

1. Близнюк М.М. До питання методики навчання засобами інформаційно-комунікаційних технологій майбутніх фахівців художньо-проектного напрямку. Проблеми інформатизації навчального процесу в школі та вищому педагогічному навчальному закладi : матер. Всеукр. наук.-практ. конф. (Київ, 10 жовтня 2017 р.). Київ: НПУ ім. М.П. Драгоманова, 2017. С. 15-16.

2. Калинкина Т.А. Вопросы использования ИКТ в художественном образовании. Научное и образовательное пространство: перспективы развития : материалы II Междунар. науч.-практ. конф. (Чебоксары, 24 апр. 2016 г.). Чебоксары, 2016. С. 123-126.

3. Морзе Н.В., Ігнатенко О.В. Методичні особливості вебінарів, як інноваційної технології навчання. URL: http://elibrary.kubg. edu.ua/918/1/N_Morze_O_Ihnatenko_ITO_4.pdf. (дата звернення: 20.03.2020).

4. Руденченко А.А. Теоретичні і методичні засади навчання етнодизайну студентів у вищих мистецьких навчальних закладах : автореф. дис. ... докт. пед. наук : 13.00.02 / Нац пед. ун-т ім. М. П. Драгоманова. Київ, 2017.42 с.

5. Фурсикова Т. Инфографика как медиаобразовательная технология в подготовке будущих учителей художественных специальностей. Аудиовизуальные медиа в условиях трансформации социокультурной среды. Минск : БГУ, 2019. С. 173-177.

6. Фурсикова Т. Основи інформатики та ІКТ в мистецькій освіті: навчально-методичний посібник. Кропивницький : РВВ ЦДПУ імені Володимира Винниченка, 2018. 120 с.

7. Халдыбетова А.И. Развивающие возможности графических программ в художественном образовании. URL: http:// gigabaza.ru/doc/126121.html (дата обращения: 20.03.2020).

\section{REFERENCES}

1. Blyzniuk M. M. Do pytannia metodyky navchannia zasobamy informatsiinokomunikatsiinykh tekhnolohii maibutnikh fakhivtsiv khudozhno-proektnoho napriamku [On the question of methods of training by means of information and communication technologies of future specialists of art and design direction]. Problems of informatization of educational process in school and higher pedagogical educational institution: mater. All-Ukrainian scientific-practical conf. (October 10, 2017). Kyiv : NPU named after M.P. Dragomanova, 2017. pp. 15-16 [in Ukrainian].

2. Kalinkina T.A. Voprosy ispol'zovanija IKT v hudozhestvennom obrazovanii [Issues of using ICT in arts education]. Scientific and educational space: development prospects: materials of the II Intern. scientific-practical conf. (Cheboksary, April 24, 2016). 2016. S. 123-126 [in Russian].

3. Morze N.V., Ihnatenko O.V. Metodychni osoblyvosti vebinariv, yak innovatsiinoi tekhnolohii navchannia [Methodical features of webinars, such as innovative technologies of science] (Last accessed: 20.03.2020) [in Ukrainian].

4. Rudenchenko A. A. Teoretychni i metodychni zasady navchannia etnodyzainu studentiv u vyshchykh mystetskykh navchalnykh zakladakh : avtoref. dys. ... d-r ped. nauk spets. : 13.00.02; Nats ped. un-t im. M. P. Drahomanova. [Theoretical and methodical bases of training of ethnodesign of students in higher art educational institutions: author's ref. dis. ... Dr. Ped. Science Special Stk : 13.00.02]. Kyiv, 2017. 42 p. [in Ukrainian]

5. Fursikova T. Infografika kak mediaobrazovatel'naja tehnologija v podgotovke budushhih uchitelej hudozhestvennyh special'nostej [Infographics as a media education technology in the preparation of future teachers of art specialties]. Audiovisual media in the context of the transformation of the socio-cultural environment. Minsk : BGU, 2019. pp. 173-177 [in Russian].

6. Fursykova T. Osnovy informatyky ta IKT v mystetskii osviti. Navchalno-metodychnyi posibnyk [Fundamentals of informatics and ICT in mystical education. An initial-methodical book]. Kropyvnytskyi : RVV TsDPU imeni Volodymyra Vynnychenka, 2018. 120 c [in Ukrainian]

7. Haldybetova A.I. Razvivajushhie vozmozhnosti graficheskih programm v hudozhestvennom obrazovanii [Developing opportunities of graphic programs in art education] (Last accessed: 20.03.2020) [in Russian]. 